"نشريه علوم زراعى ايران"

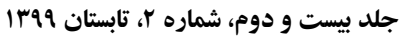

مقاله ئوهشى

ارزيابى اثر يراكنش مكانى علفهاى هرز بر عملكرد دانه عدس (Lens culinaris L.) در شرايط ديم Evaluation of the effect of spatial distribution of weeds on seed yield of lentil (Lens culinaris L.) in rainfed conditions

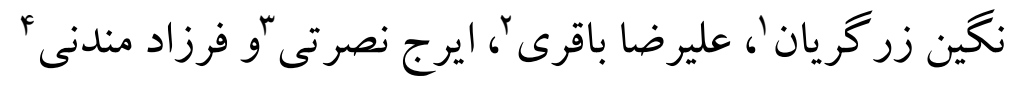

דكيده

زركريان، ن.، ع.ر. باقرى، ا. نصرتى و ف. مندنى. و9 1ا. ارزيابى اثر براكنش مكانى علفهاى هرز بر عملكرد دانه عدس (Lens culinaris L.) در شرايط ديـم. نشريه

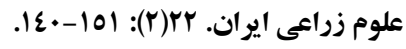

علفهاى هرز يكى از مهم ترين عوامل كـاهش عملكــد در كياهـان خـانواده بقـولات هـــنـد، بنـابراين آكـاهى از بـرهمكنش

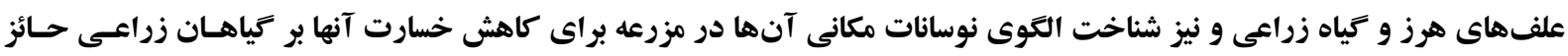
اهميت است. به منظور ارزيابى اثر علفهاى هرز بر عملكرد دانه عدس و بروسى الكوى توزيع مكـانى آنهـا، آزمايشى طـى سلى سـال

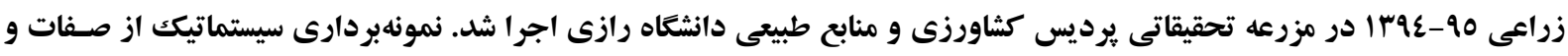
شاخصهاى علفهاى هرز شامل تراكم، درصد تاج بوشش، ارتفاع و وزن خشك بوته و كيـاه عـدس شـامل درصـد تـاج يوشـش و عملكرد دانه در دو مرحله قبل از كلدهى و در زمان رسيدكى فيزيولوزيكى عدس انجام شد. روابط بين علـفهــاى هـرز و عملكـرد دانه عدس با استفاده از روابط ركرسيونى و نقشههاى مربوط به صفات علفهاى هـرز و عـدس نيـز بـا استفاده از روش درونيـابى كريجينك استخراج شدند. نتايج نشان داد كه با افزاي تراكم و درصد تاج بوشش علفهاى هرز از صفر تا •ا (بوته در متر مربـع و

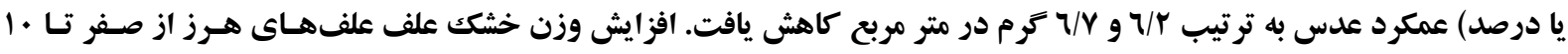
كرم در متر مربع منجر به كاهش عملكرد عدس به مقدار ع/ كرم در متر مربع شد. نقشهاى توزيع مكانى نيز نشـاندهنده تغييـرات

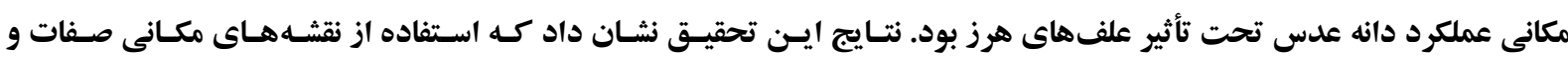
شاخصهاى علفهاى هرز و عدس در كنار روشهاى مرسوم، روش تكميلى دقيق و مناسبى جهت در ك و تفسير بهتر روابـط بـين آنها است.

وازههاى كليدى: بقولات، رقابت علفهاى هرز، زمين آمار، كاهش عملكرد و عدس.

\footnotetext{
اين مقاله مستخرج از رساله كارشناسى ارشد نگارنده اول مىباشد.

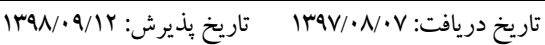

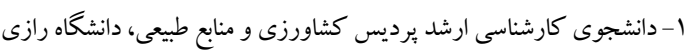

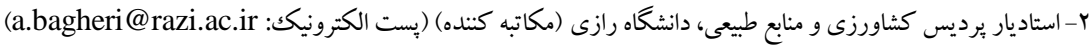

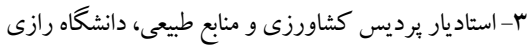

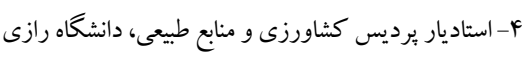


عواملى نظير عمليات خاككورزى و مصرف نهادهها نيـز

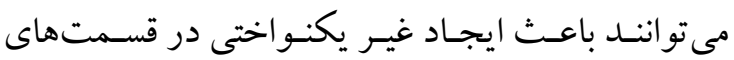

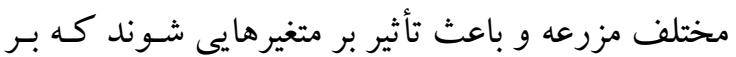
عملكرد محصول تأثير مى گذارنسد (Liu, et al., 2013).

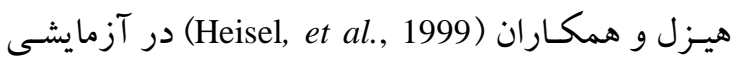
نشان دادند كه نوسانات مكانى عناصر غذايى موجود در در

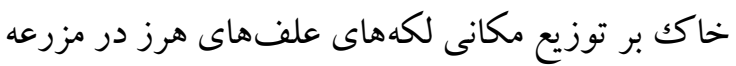

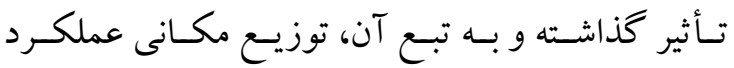
محصول نيز تحت تأثير قرار مى گيرد.

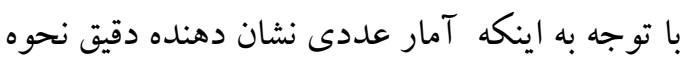

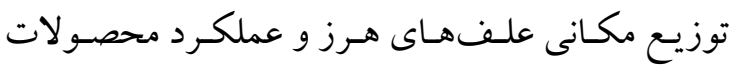
نيست، محققان براى تحليل جنين اطلاعاتى از نقشـههاى

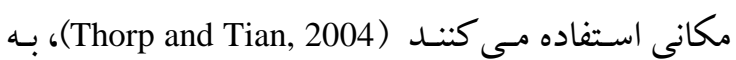

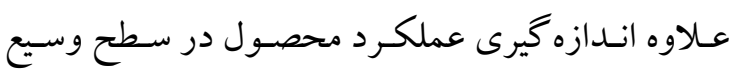
مستلزم صرف هزينه و وقـت زيـادى مسىشـود، بنـابراين

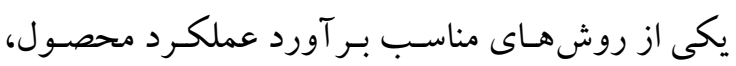

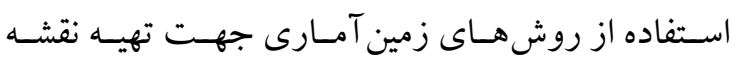
عملكـرد اسـت (Seyed Jalali and Shorafa, 2016). در ايسن روش معمـولا نقــاط نمونـهبردارى بــر اســاس

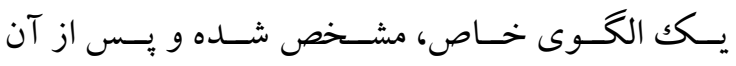

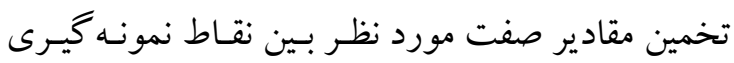

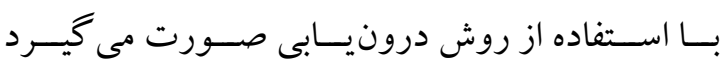
(Koller and Lanini, 2005) روشهاى درونيابى، روش درونيابى كريجينگ است.

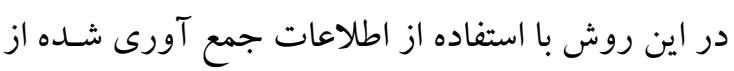

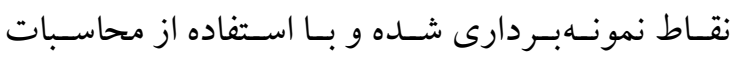

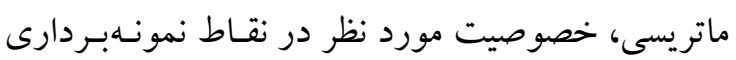

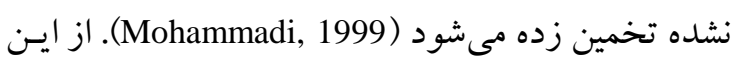

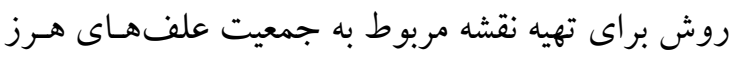

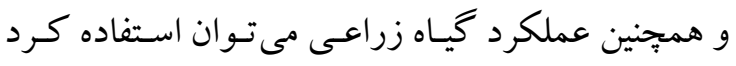

.(Bagheri, et al., 2014)

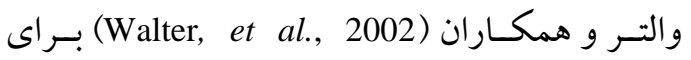

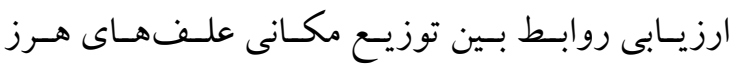

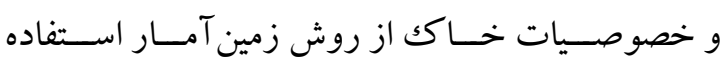

\section{مقدمه}

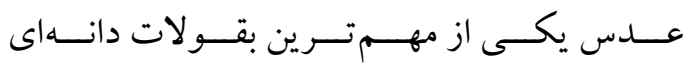

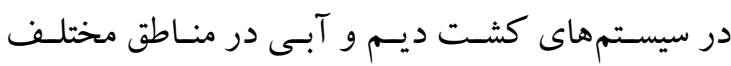

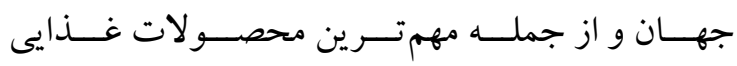

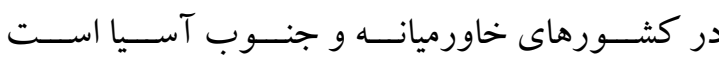

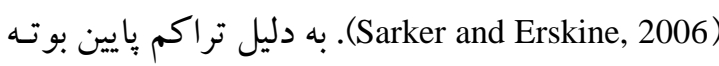

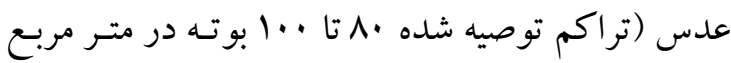

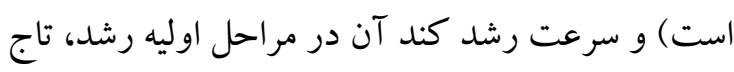
يوشش مزرعه عدس در ابتداى فصـل رشـد كـم تـراكم

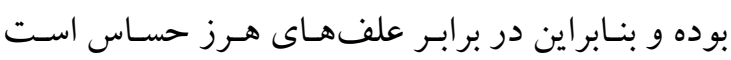
(Erman, et al., 2008)

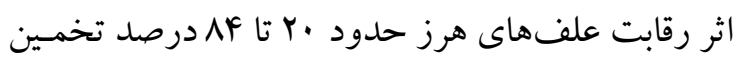
زده شده است (Yenish, et al., 2009). علف هرداى هـر بر سر رطوبت، عناصـر غـذايى، نـور و فضـا بـا كياهـان

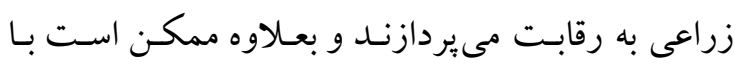

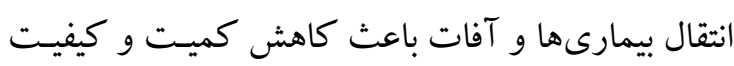
محصسول شـوند (Saxena, et al., 1976). در شـرايط

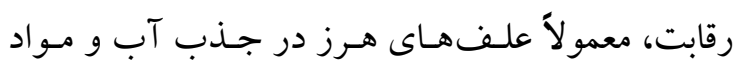
غذايى نسبت به گياه زراعى موفقتر عمل كل كرده و ايسن

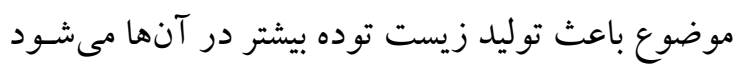

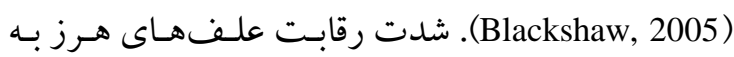
كونه علف هرز، شدت آلودگگى، دوره تداخل و شرايط

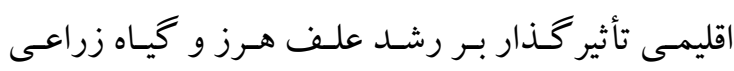

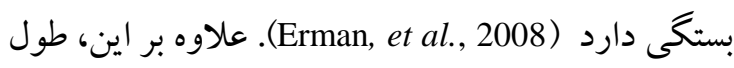

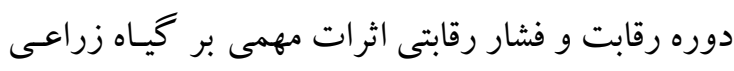

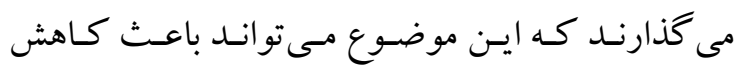

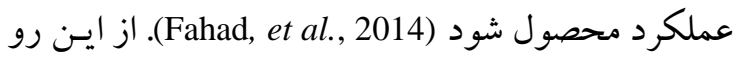
كنترل علف هاى هرز عدس جهت جلو گيرى از كاهش

$$
\text { محصول ضرورى است. }
$$

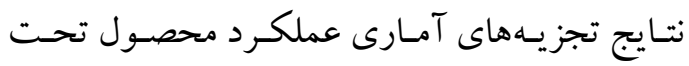

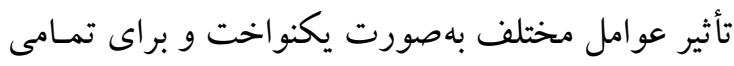

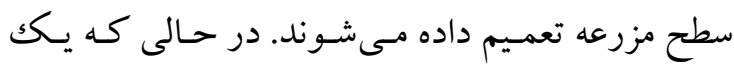

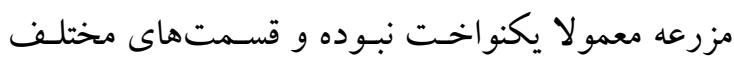

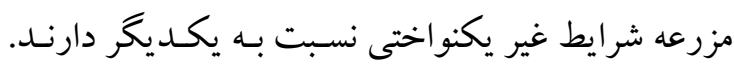




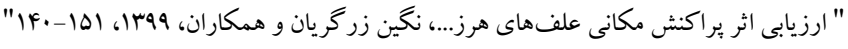

صفات تأثير گذذار مربـوط بـه علفهـاى هـرز در مزرعـهـ

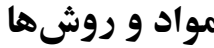

اين آزمايش در سـال زراعى هوادو روسها

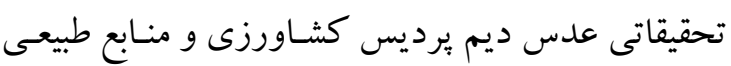

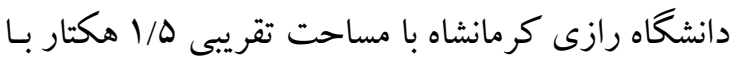

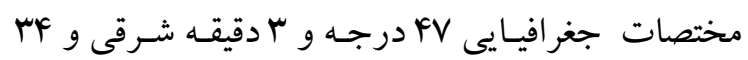

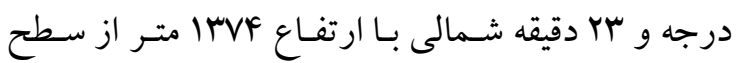

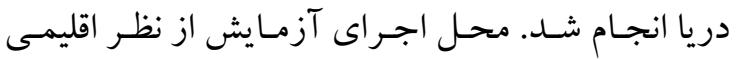

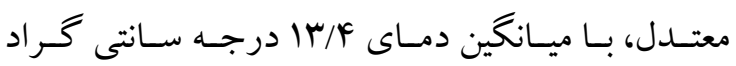

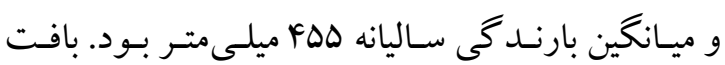

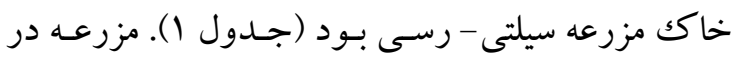

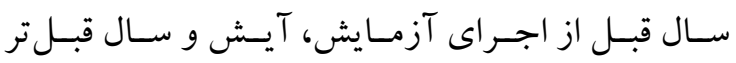

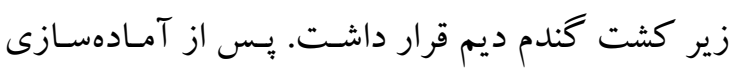

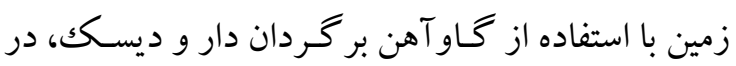

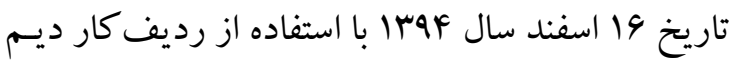
با فاصله رديف و بوته به ترتيـب ه و و هـانتىمتر، بـذر

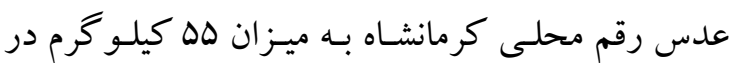

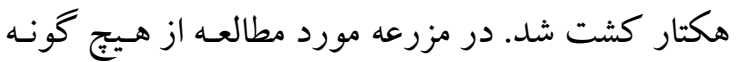

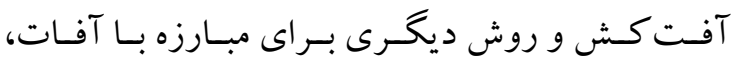

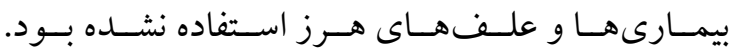

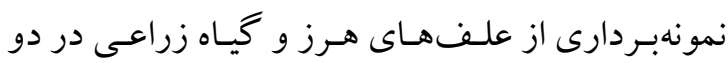
مرحله انجام شد.
كردنـد. اشـرفى و همكـاران (Ashrafi, et al., 2004)

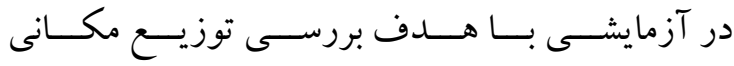

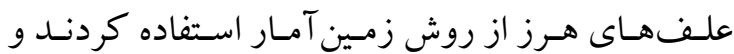

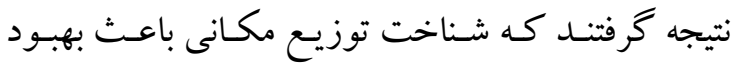
تصسميم گيـرىهـاى مـديريتى و شناسـايى بهتـر نحسوه

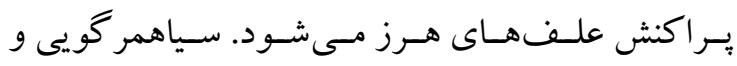
همكاران (Siah Marguee, et al., 2006) نيز در تحقيقى در مزارع جغندرقند جهت بيان الكوهاى تغييرات مكانى

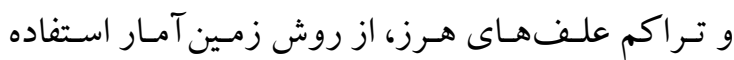
كردند و گززارش كردند كه در دست داشـتن اطلاعـاتى

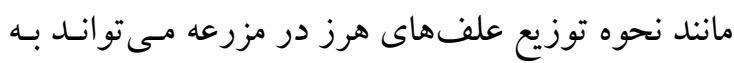

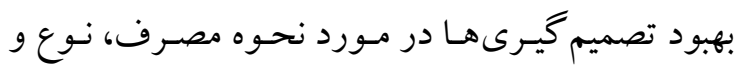
ميز ان مصرف علف كشها كمكك كند. در دست داشتن

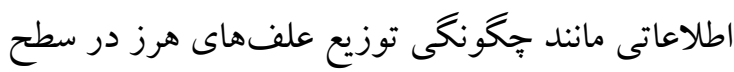

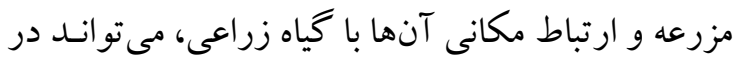

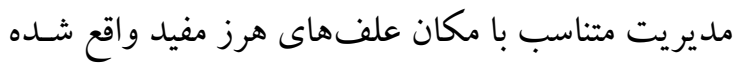

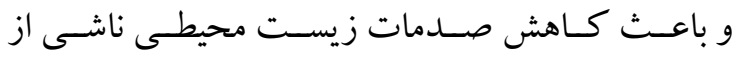

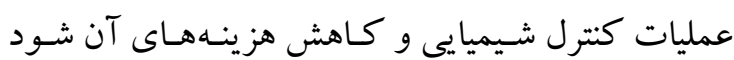

.(Makarian and Rohani, 2014) بـا توجـهـ بـهـ اهميـت علفهــاى هـرز در كــاهش محصول عدس ديم در مناطق غربى ايران، هدف از ايـن تحقيـق بررسى اثر صـفات و شـاخص هاى مربـوط بـهـ علفهـاى هـرز در كـاهش عملكـرد عـدس و همجينـين

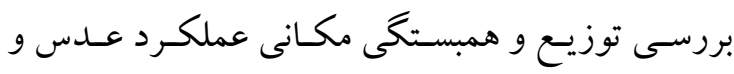

جدول ا- ويز گى هاى فيزيكى و شيميايى خاك مزرعه محل اجراى آزمايش

Table 1. Physical and chemical properties of the soil of experiment site

\begin{tabular}{|c|c|c|c|c|c|c|c|c|}
\hline $\begin{array}{c}\text { بافت } \\
\text { Texture }\end{array}$ & $\begin{array}{c}\text { رس) } \\
\text { Clay (\%) } \\
\end{array}$ & $\begin{array}{c}\text { سيلت } \\
\text { Silt (\%) }\end{array}$ & $\begin{array}{c}\text { ش } \\
\text { Sand }(\%)\end{array}$ & $\begin{array}{c}\text { كربن آلى (\%) } \\
\text { Organic carbon }\end{array}$ & $\begin{array}{l}\text { نيتروزن } \\
\text { N (\%) }\end{array}$ & $\begin{array}{l}\text { اسيديته } \\
\text { pH }\end{array}$ & 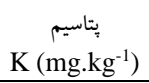 & $\begin{array}{c}\text { ف فسفر } \\
\text { P (mg.kg-1) } \\
\end{array}$ \\
\hline Clay-Silt & 42.8 & 48.6 & 8.7 & 1.5 & 0.16 & 7.3 & 279.6 & 21.3 \\
\hline
\end{tabular}

حركـت در مزرعسه قـرار داشـته و در هريـك از نقــاط،

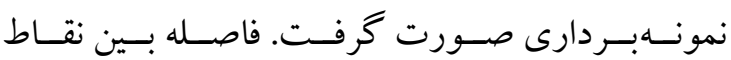

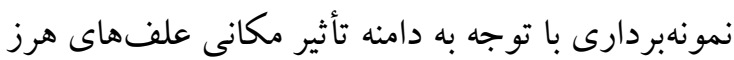

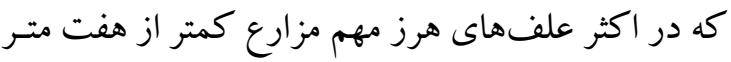

نمونهبردارى در مزرعه به صورت سيستماتيك انجام

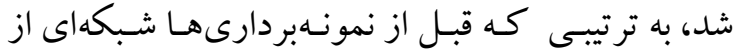
نقاط فرضى مربعى (با فواصـل هفـت در هفـت متـر ) در

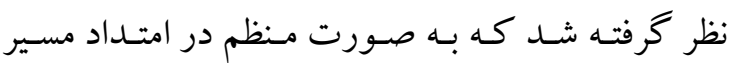


غير تخريبى شامل تراكم بوته، ارتفاع بوته و درصد تـاج

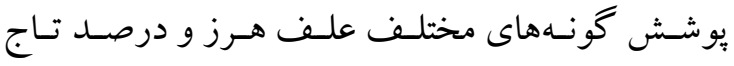

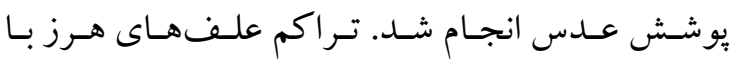

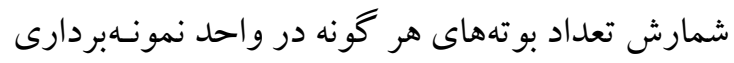

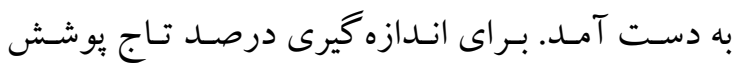

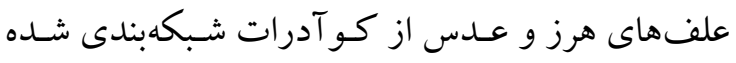

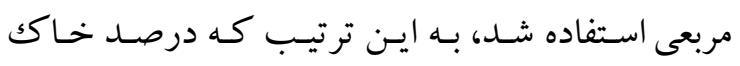

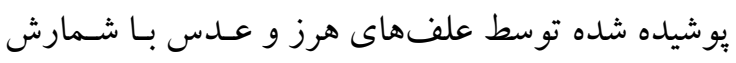

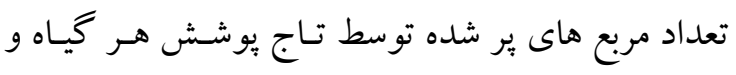

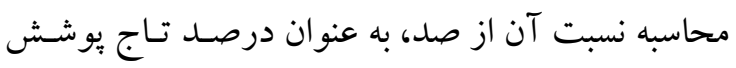
در نظر كرفتـه شــ (Brim-DeForest, et al., 2017).

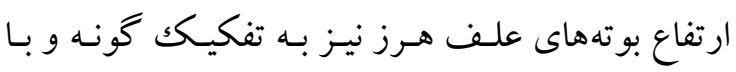

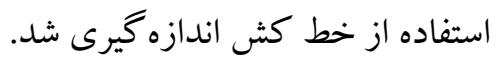

اسـت (Bagheri, et al., 2010)، هفــت متــر در نظـر كرفته شده و براى تعيين سطح محل نمونهبردارى نيـز از

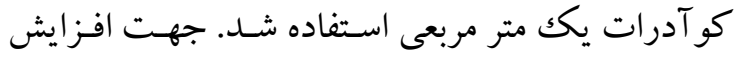
دقت كار و يكسان بودن بررسى نقـاط نمونسهبردارى در

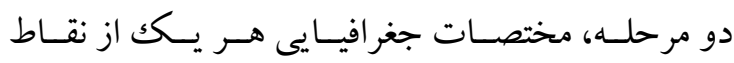
با استفاده از دستخاه جى يى اس ثبت و و جهـت شناسـايى

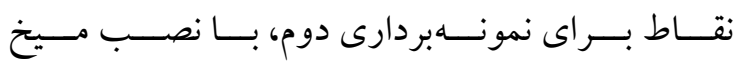

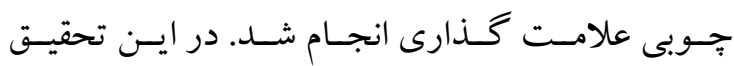

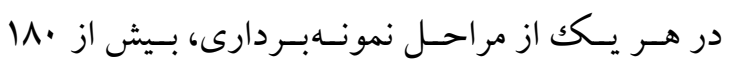

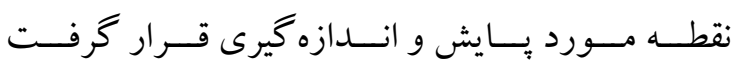

در اولين نمونهبردارى كه مصادف بـا مرحلـه قبـل از

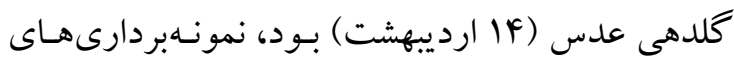

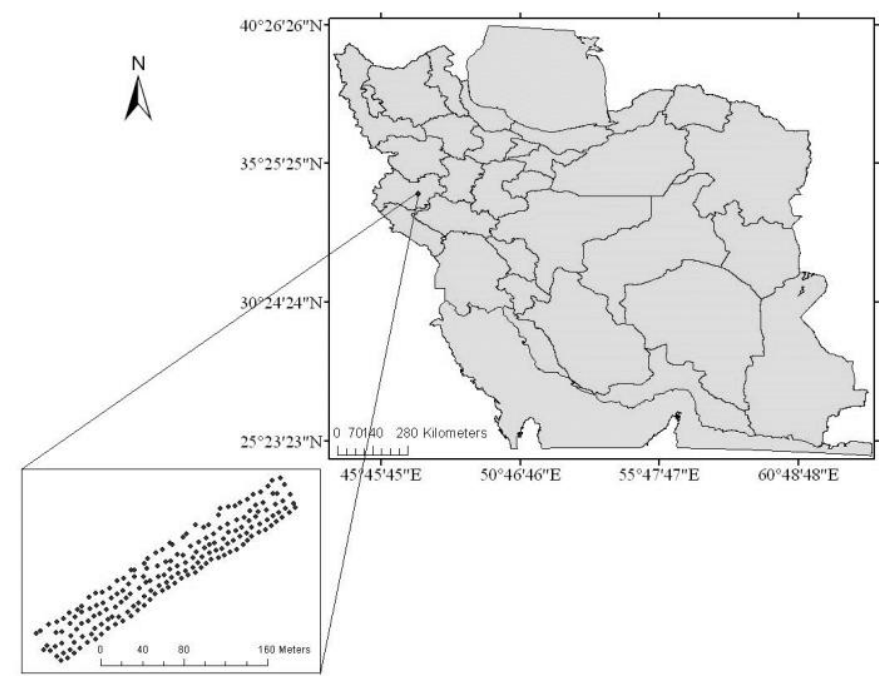

شكل ا- نماى كلى از محدوده محل اجر ایى آزمايش و نمونهبردارى سيستماتيك

Fig. 1. General view of the experiment site and systematic sampling

عملكرد دانه عدس و وزن خشك علف هاى هرز بِ از

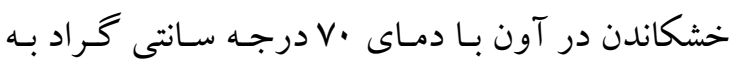
مدت VY ساعت، اندازه خيرى شدند.

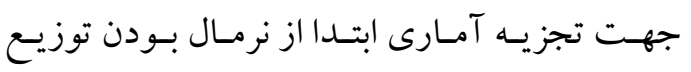

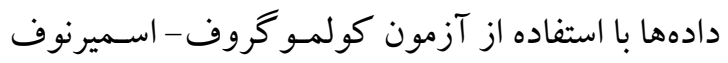

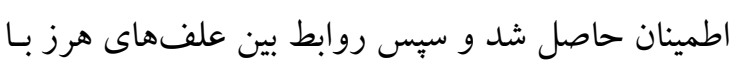

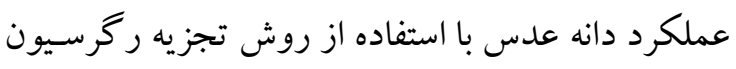

در نمونهبردارى دوم، در انتهاى فصـل رشـد و زمـان

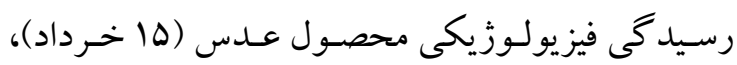

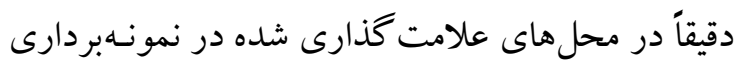
اول، نمونهبردارى به صورت تخريبى انجام شد، بـهـ ايسن

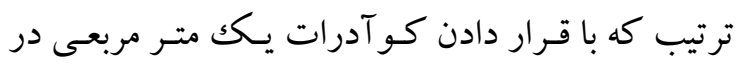

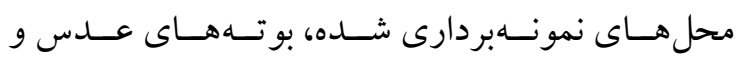
علفهاى هرز جمع آورى و به آزمايشكاه منتقل شـده و و 


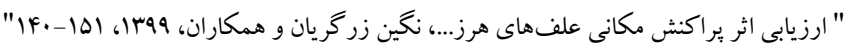

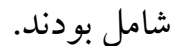

نتايج مربوط به ارزيابى اثر تراكم بوتسه، درصسد تـاج يوشش و ارتفــاع بو تـه علـف هــاى هـرز، بـهـعنوان متغيـر مستقل بر عملكرد دانه عدس بهعنوان متغير وابسته، نشان

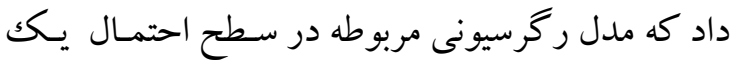
درصــ معنسى دار بـوده و توجيسه كنتـده تغييـرات متغيسر وابسته تحت تأثير متغيرهاى مستقل بود. بر اسـاس نتـايج به دست آمده، عملكرد دانه عدس به طور قابـل تو جهى

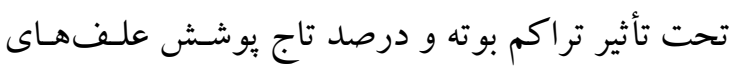

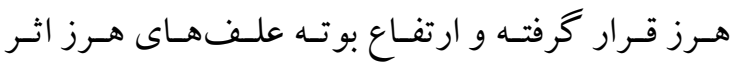
معنى دارى بر عملكرد عدس نداشتند (جدول r).

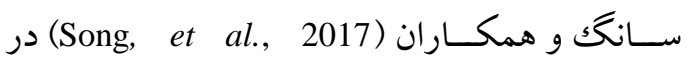

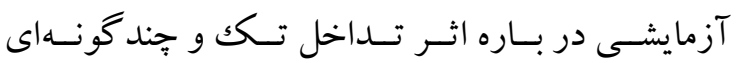
علفهاى هرز در مزرعه سويا بيان داشـتند كه عملكـرد دانه سويا بـه طـور قابـل ملاحظهاى تحـت تـأثير تـراكم مرك علفهاى هرز قرار داشت. تراكم بالاى علف هـاى هـرز مىتواند فشار رقابتى بالا در طى فصل رشـد، بخصـوص در دوره بحر انى علف هاى هرز را به دنبـال داشـته باشـــ.

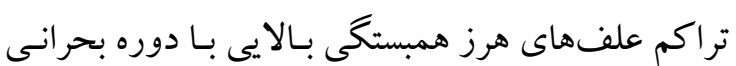

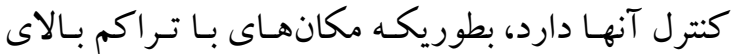
علف هرز دوره بحرانى كو تاهتر از مكانهـاى بـا تـراكم كم تا متوسط را دارند. اين موضسوع نشـان دهنـده تـأثير بيشتر علفهاى با تراكم بالا در زمان كمتر و لزوم توجه بيشتر براى كنترل آنها است (Myers, et al., 2005). در آزمايش مايرس و همكاران (Myers, et al., 2005)عـدم كنترل علف هاى هرز در تراكمهاى كم (باّوتـه در متـر مربع)، متوسط (F| بوته در متر مربع) و زياد (49بوته در متر مربع) علف هـرز سـور گوم باعـث كـاهش عملكـرد

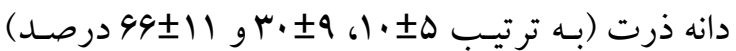

شد.

نقشـه توزيـع مكـانى عملكـرد دانسه عـدس و تـراكم علفهاى هرز نيز نشان داد كه اكثر نقاط با تراكم بالاى

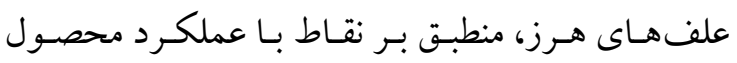
كمتر عـدس بـود (شـكل ب). در ايسن رابطـه مكاريـان و
محاسبه و روابط خطى بين خصوصيات علف هاى هرز و عملكرد دانه عدس مورد بررسى قرار كرفتـه و ضـرايب مربوط به معادلات خطوط ركرسـيونى بدست آمــده بـا

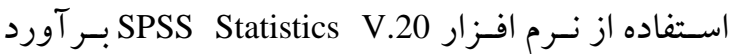
شدند. ضريب بتا در ر گرسيون جهت بررسى ميزان تأثير متغيرهاى مستقل (خصوصيات مربوط به علفهاى هرز) روى متغير وابسته (عملكرد عدس) در نظر كرفته شد.

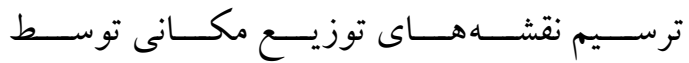

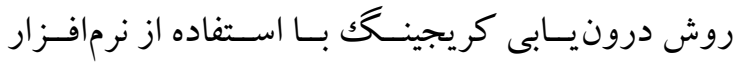
ArcMap 10.2.2 انجام شد. در ايـن روش بــراى انتخـاب

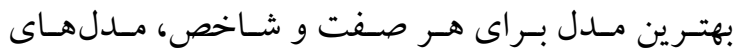
مختلف مورد استفاده قرار كرفتـه و مــلى كـه كمتـرين ريشه دوم ميانكين مربعات خطا (RMSE) را داشـت، بــ مورده عنوان بهترين مدل انتخاب و نقشه بر اساس آن تهيه شد.

\section{نتايج و بحث}

نتــايج نشــان داد كــهـه در نمونــهـه بــــدارى اول در

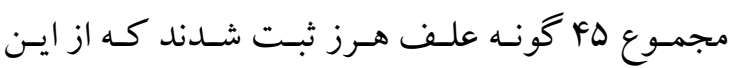

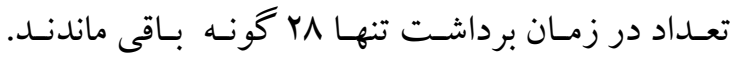
يرتراكمترين كونه هاى علف هرز در نمونه بـردارى اول شــامل فرفيـــون (Euphorbia rigida)، ســـلمه تـــــه (Cardaria draba) (Chenopodium album) ازمـكـ (C) شـمعدانى غــدمدار (Geranium tuberosum)، علــف

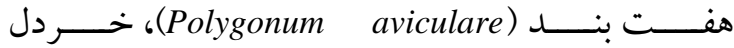
وحشـــ arvensis (Sinapis ) بي

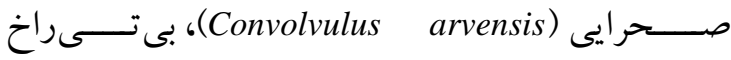
(Galium aparine) كوش خر گَوش (Conringia orientalis)، خـار زردك (Picnomon acarna)، شـقايق (Papaver umbonatum)، (Convolvolus

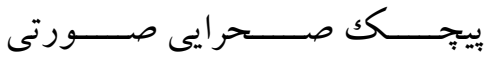

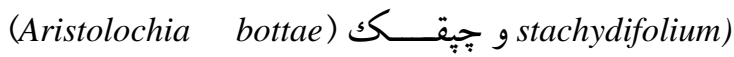
بودند كه در مجموع حدود 91 درصد از كل علفهـاى. هرز را تشكيل مى دادنسـ. خـانوادههـاى Brassicaceae، Asteraceae و بيشــ Convolvulaceae 


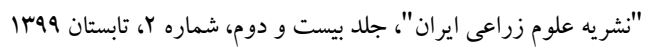

جدول r- رابطه ركرسيونى تراكم بو ته، درصد تاج بوشش، ارتفاع بوته علفهاى هرز و عملكرد دانه عدس (نس

$$
\text { (نمونه بردارى اول) }
$$

\begin{tabular}{|c|c|c|c|c|}
\hline $\begin{array}{c}\text { مدل } \\
\text { Model } \\
\end{array}$ & $\begin{array}{c}\text { ضريب رگرسيون } \\
\text { Regression coefficient } \\
\end{array}$ & $\begin{array}{c}\text { خطاى معيار } \\
\text { Standard error }\end{array}$ & $\begin{array}{c}\text { ضريب بتان } \\
\text { Beta coefficient } \\
\end{array}$ & $\begin{array}{c}\text { مقدار احتمال } \\
\text { P value }\end{array}$ \\
\hline ضريب ثابت & 217.2 & 13.8 & - & 0.00 \\
\hline تراكم بوته علفهاى هرز & -0.62 & 0.18 & -0.26 & 0.00 \\
\hline $\begin{array}{c}\text { درصد تاج يوشش علفهاى هرز (\%) } \\
\text { Canopy cover of weed }\end{array}$ & -0.67 & 0.17 & -0.26 & 0.001 \\
\hline $\begin{array}{l}\text { ارتفاع بو ته علفهاى هرز } \\
\text { Plant height of weed }\end{array}$ & 0.72 & 0.46 & 0.11 & 0.12 \\
\hline
\end{tabular}

Table 1. Regression relationship between weed density, canopy cover, plant height of weed and seed

همــراه دارد. در ايسن آزمـايش در نقـاطى از نقشـه كـهـ

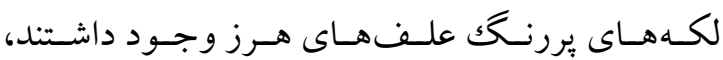
عملكرد دانه عدس بـايين بـود (شـكل Y). البتـه نقـاطى

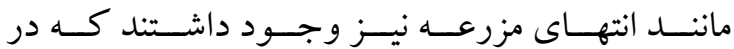

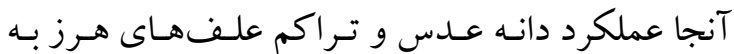
طور مشابه افزايش يا كـاهش داشـتند كـه ايسن موضـوع ممكن است به دليـل شـرايط خـاص آن نقطه از مزرعـه

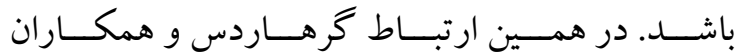
گز ارش كردند كه در نقـاطى (Gerhards, et al., 2005) از مزرعه كه شدت آلـودگى بـه علـف هـاى هـرز بيشـتر بود، عملكرد محصول بيشتر بود كه با بررسى نقشههـاى كيفيـت خـاكك ايسن موضـوع را بـا حاصـلخيزى بيش تـر خاكك در اين نقاط مرتبط دانستند.
حسـينى (Makarian and Hosseini, 2010) نيـز در يـك آزمايش در باره ارتباط مكانى بين تراكم علفهاى هرز و زيست توده كندم گزارش دادند كه الكوهـاى توزيـع مكانى علف هاى هرز به مقــدار قابـل تـوجهى منطبـق بـر الكوهاى تغيير زيست توده كندم بودند كه اين موضسوع

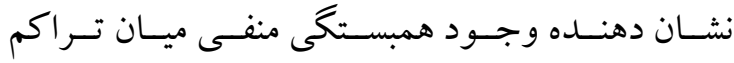
علف هاى هرز و عملكرد كندم است. والتـر و همكـاران نيـز گـزارش دادنـد كـه نحسوه (Walter, et al., 2002) توزيع علفهاى هرز در مزرعه با توجه بـه خصوصسيات خاكك تغير كـرده و در نتيجـه حضـور علـفهـى هـرز در نقاط حاصلخيز مزرعه باعث تخليه منـابع و بـه دنبـال

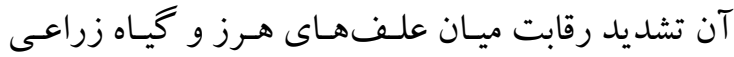
شــده و در نهايست كــاهش عملكــــد محصـول را بــه

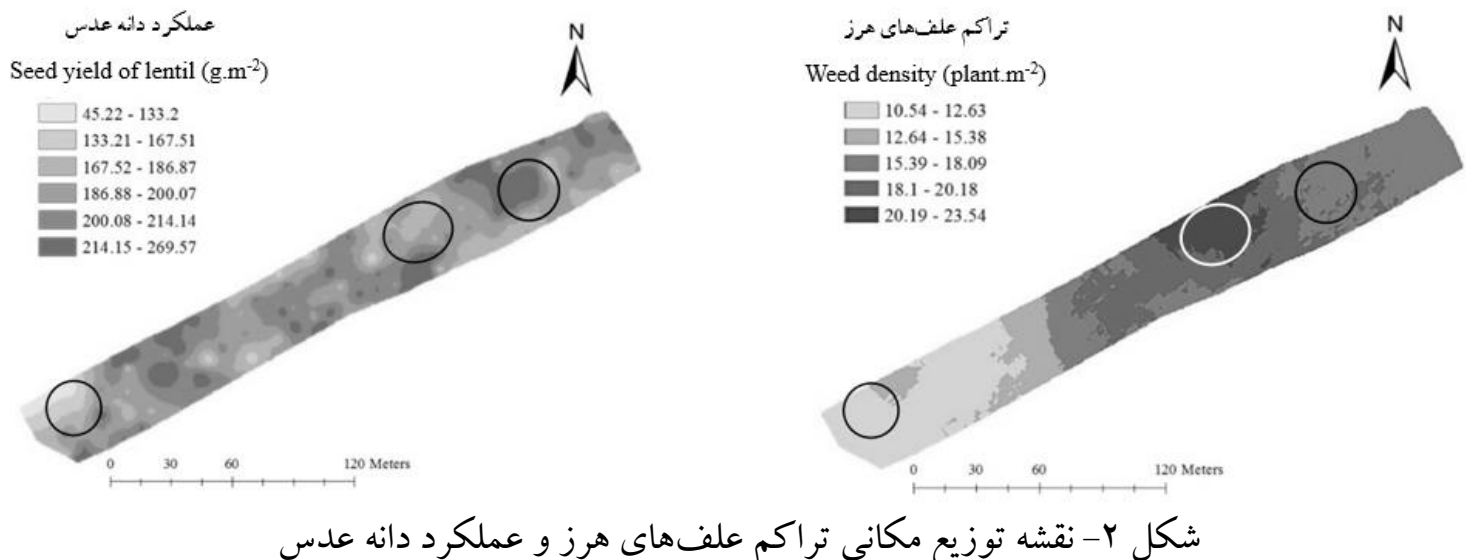

Fig. 2. Spatial distribution map of weed density and seed yield of lentil 
كه درصد تاج يوشش علفهاى هرز بالا بـود، مشـاهده شد. مقايسه نقشه هاى درصد تـاج يوشـش علـف هـرز و عدس نيز مويد اين موضوع بوده و يكك همبستكى منفى

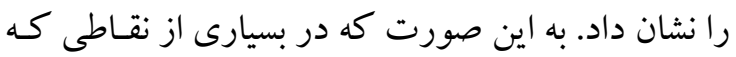
درصد تاج بوشش علف هاى هرز بالا بـود، درصـد تـاج

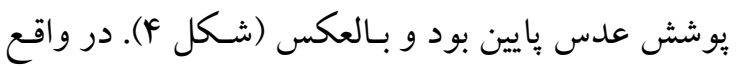

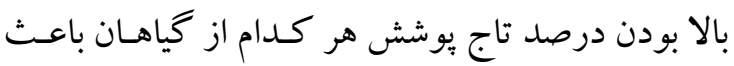

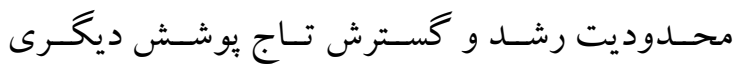
مىشود. بـهـ همـين دليـل اسـت كـه افز ايش سـطح تـاج بوشش و ارتفاع بوته مىتواند توان رقابتى آن گياه را در برابر گياه ديخر افزايش دهـد (Lehnhoff, et al., 2013) و كشت ارقامى با رشـد اوليـه سـريع و تشـكيل سـريعتر تــاج بوشـش متــراكم روى ســطح خــاك، قــدرت فرونشـانى بيشـتر علـفـهـاى هـرز را بــه همــراه دارد .(Liebman and Dyck, 1993) نتايج مربوط به اثر تراكم و وزن خشـك علـفهـاى هـرز در نمونسهبردارى دوم (بـهعنوان متغيـر مسـتقل) بـر عملكرد دانه عدس (بهعنوان متغير وابسته) نشـان داد كـه مدل ركرسيونى مربوطه در سـطح احتمـال يـك درصــ معنى دار بوده و قادر به بيان تغييرات متغير وابسـته تحــت تأثير متغير هاى مستقل بود. نتايج نشـان داد كـه عملكرد

عملكرد داته عدس

Seed yield of lentil (g.m- $\left.\mathrm{m}^{-2}\right)$

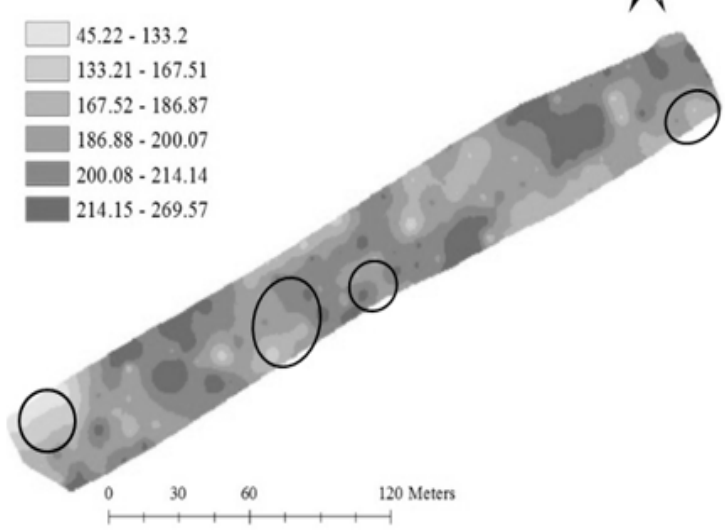

علاوه بر تراكم بوته، درصد تاج يوشش علـفهـاى هرز نيز بر عملكرد دانـه عـدس اثـر منفى و معنى دارى داشت (جدول Y). كياهان در اثـر افزايش تـاج بوشـش كياهان مجاور، تحت تـأثير قرار كرفتـه و كـاهش تـاج يوشش كياه زراعى باعـث كـاهش جـذب تـابش فعـال فتو سـنتزى مىشـود (Schroeder, et al., 2005). در حقيقت، جذب تابش توسط تاج بوشـش گيـاهى باعـث تغيير نسبت نور قرمز به مادون قرمز ميىشود. تغيير نسـبت نور قرمز به مادون قرمز به دليل حضور كونههاى گياهى رقيب، مىتواند باعث تغيير خصوصسيات مورفولوزيكى

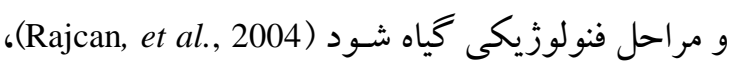
در نتيجه مى توان نتيجه گرفت كـه افزايش درصـد تـاج يوشش علف هاى هرز باعث كاهش دريافت تابش فعـال فتوسنتزى توسط كياه زراعى و در نتيجه كاهش فتوسنتز و عملكرد آن مىشود. تطابق نقشههاى عملكرد دانسه عـدس و درصـد تـاج يوشش علف هاى هرز نقـاطى را نشـان داد كـه در آنجـا بالا بودن درصد تاج بوشش علف هرز، كاهش عملكرد محصول عدس را به دنبال داشت (شكل س). علـفهـاى هرز با اشغال فضا، از كسترش تاج بوشـش كيـاه عـدس

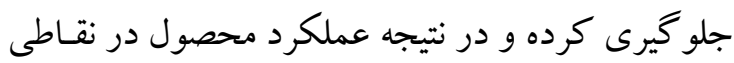

درصد تاج بوشش علفهاى هرز

Weed canopy percentage

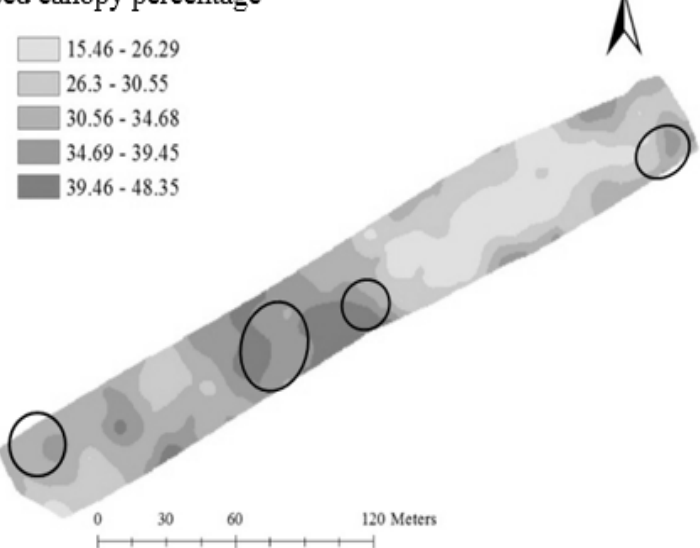

شكل ب- نقشه توزيع مكانى درصد تاج بوشش علف هاى هرز و عملكرد دانه عدس

Fig. 3. Spatial distribution map of weed canopy percentage and seed yield of lentil 


$$
\text { "نشريه علوم زراعى ايران"، جلد بيست و دوم، شماره r، تابستان ج9911 }
$$

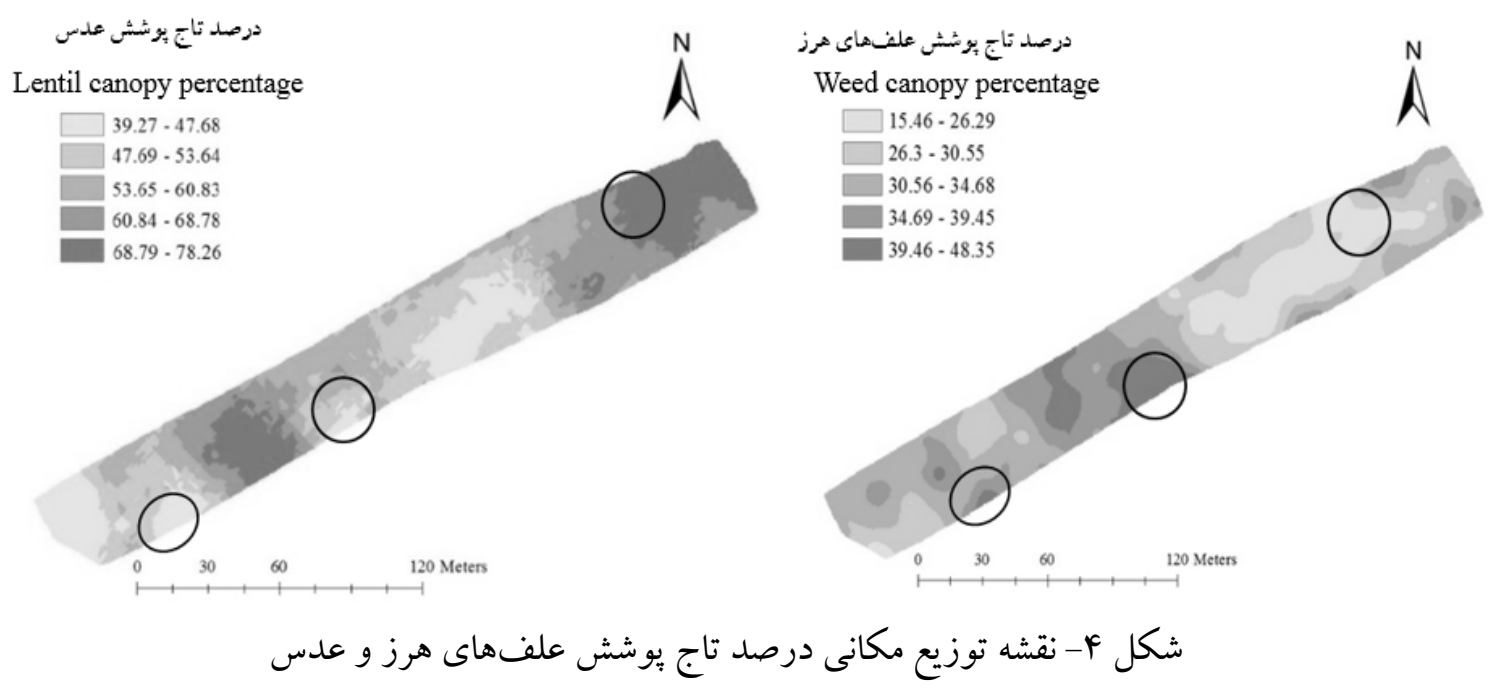

Fig. 4. Spatial distribution map of weed and lentil canopy percentage

كزارش كرده و بيان كردنـد كهه بـه ازاى هـر كيلـو كرم

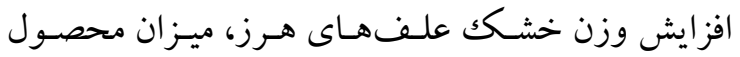

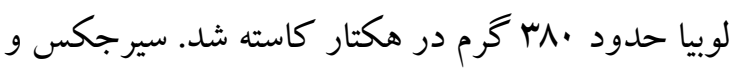

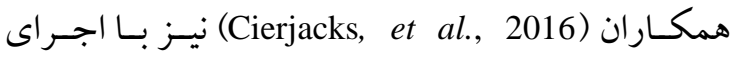

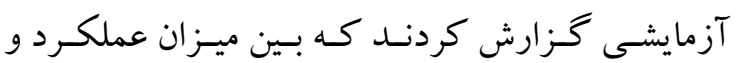

وزن خشك علف هاى هرز همبستخى منفـى معنى دارى

$$
\text { وجود داشت. }
$$

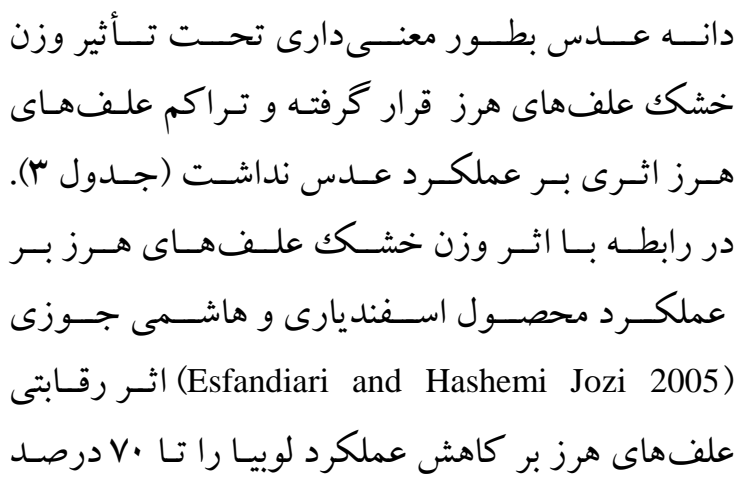

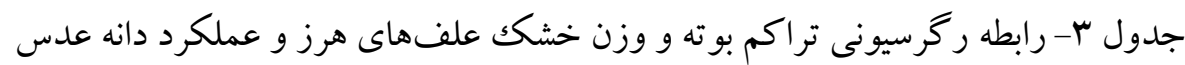

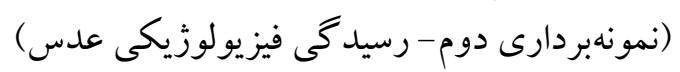

\begin{tabular}{|c|c|c|c|c|}
\hline $\begin{array}{c}\text { مدل } \\
\text { Model }\end{array}$ & $\begin{array}{c}\text { ضريب رگرسيون } \\
\text { Regression coefficient }\end{array}$ & $\begin{array}{c}\text { خطاى معيار } \\
\text { Standard error }\end{array}$ & $\begin{array}{c}\text { ضريب بتا } \\
\text { Beta coefficient }\end{array}$ & 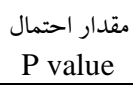 \\
\hline ضريب ثابت & 214.707 & 5.105 & - & 0.000 \\
\hline تراكم علفهاى هرز & -0.488 & 0.501 & -0.075 & 0.331 \\
\hline وزن خشك علفهاى هرز & -0.247 & 0.099 & -0.193 & 0.013 \\
\hline
\end{tabular}

Table 2. Regression relationship between weed density and weed dry weight and seed yield of lentil

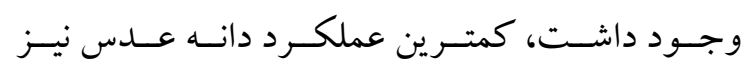

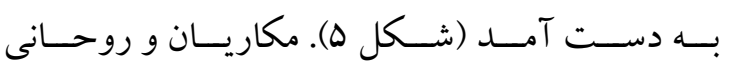

نيز با ارزيابى نقشههاى (Makarian and Rohani, 2014)
نقشـهـ مربـوط بـه وززن خشـك علـف هــاى هـرز و

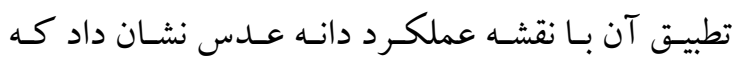

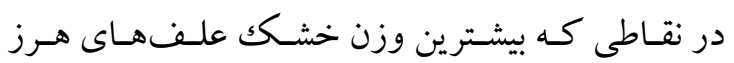




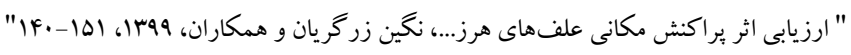

عملكـرد محصـول در سراسـر مزرعسه مـى شـود، زيــرا در نقاطى كه لكههاى علفهـاى هـرز ديــده مسىشـود، رقابت براى منابع بيشتر بـوده و بنـابراين در همـان نقـاط

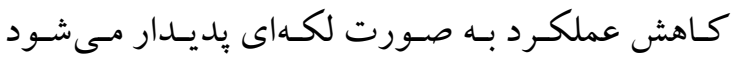

.(Milberg and Hallgren, 2004)

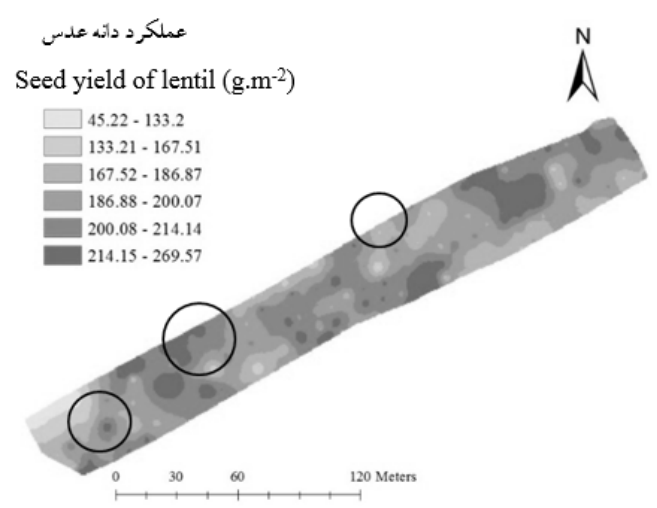

توزيع عملكرد كندم در دو مزرعه گَز ارش كردنـد كـه نقاط داراى عملكرد كمتر دانه گُندم تا حسدودى منطبـق بر نقاطى بود كه وزن خشكك علفهاى هرز بيشـتر بـود. در واقـع توزيـع لكـهاى زيسـت تـوده علـف هــاى هـرز

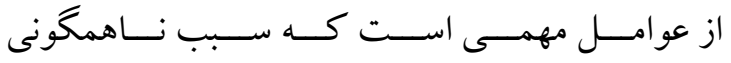

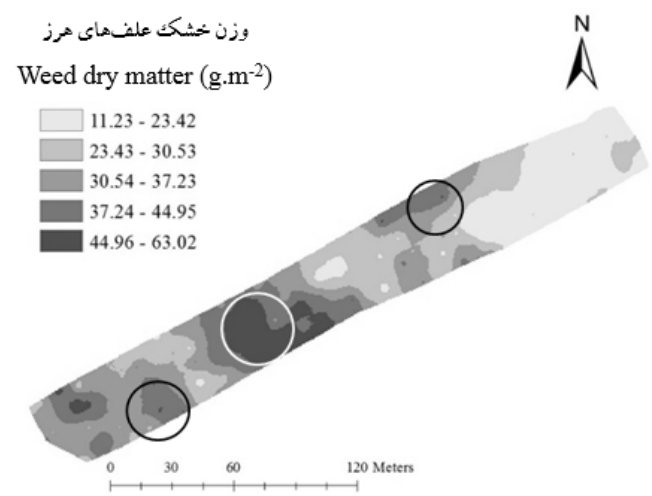

شكل ه- نقشه توزيع مكانى وزن خشك علف هاى هرز و عملكرد دانه عدس

Fig. 5. Spatial distribution map of weeds dry matter and seed yield of lentil

علف هاى هـرز بـا بهره گيـرى از سيسـتم هـاى هوشـمند توزيع غير يكنو اخت علف كشها در مزرعه و مبتنى بـر توزيع مكانى جمعيت علف هاى هرز، مـديريت بيشـرفته علف هاى هـرز امكان بــذير مىشـود كـه ايسن موضـوع

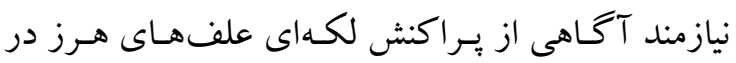
سطح مزرعه است. با توجه به اينكه آمار كلاسيك قـادر

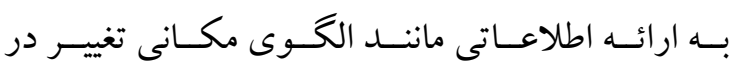
خصوصيات كياه زراعى و علفهاى هرز نيست، در اين تحقيق نشان داده شد كه استفاده از نقشههاى بـراكنش

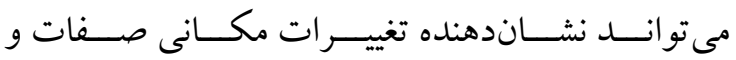

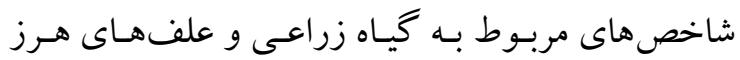

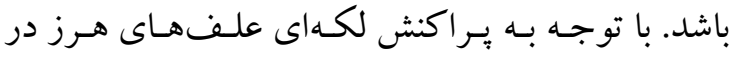
مزرعه و در نتيجـه اثـر متفــاوت آنهـا بـر كيـاه زراعى، اعمال مــديريت متناسـب بـا مكـان لكـهــاى آلـوده بـــ علفهاى هرز مى تواند علاوه بر افزايش عملكـرد گيـاه زراعى، مزايايى از جمله صرفهجويى در وقت و هزينه و

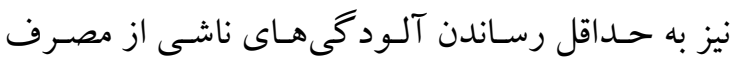
علف كشها را به همراه داشته باشد.

\section{نتيجه Fيرى}

نتايج تحقيق حاضر نشان داد كه تراكم بوته، درصــ تاج بوشش و وزن خشكك علـفهـاى هـرز از عـواملى هستند كـه باعـث كـاهش معنسى دار عملكـرد محصـول عدس مىشوند. مقايسه نتايج مربوط به نمونهبردارىهاى

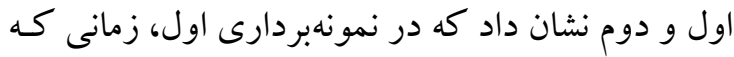

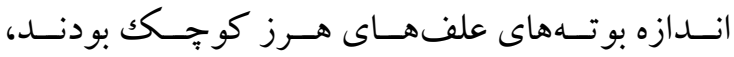
شاخصهاى تعيين كننده آنها بـر عملكرد دانسه عـدس، تراكم بوته و تاج يوشـش آنها بودنسل. در نمونسهبردارى

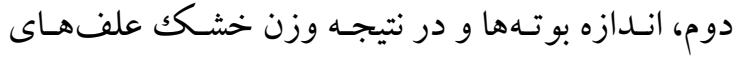
هرز عامل تعيين كننده در كـاهش عملكـرد دانـه عـدس بود. نتايج نشان داد كه كاهش عملكـرد دانـه عـدس در نقاط مختلف مزرعه يكسان نيست، زيـرا در قسمتهاى مختلف مزرعه تراكم بوتـه، درصــ تـاج يوشـش و وزن خشك علف هاى هرز و ميزان محصول عـدس متفـاوت بودند. شـناخت ايسن نـاهمكونى مى تو انـد امكـان اعمـال مديريت متناسب با مكان در قسمتهاى مختلف مزرعـه را فـراهم آورد. در مــديريت متناسـب بـا توزيـع مكـانى مري 
Ashrafi, A., M. Banayan.Aval and M. H. Rashed.Mohasel. 2004. Spatial dynamics of weed populations in a corn field using geostatistics. Iran J. Field Crops Res. 1(2): 139-154. (In Persian with English abstract).

Bagheri, A., M. H. Rashed Mohasel and P. Rezvani Moghaddam. 2014. Effect of crop rotation on spatial dynamic of Fumaria vaillantti and Polygonum aviculare. Iran J. Field Crops Res. 12(2): 178-188. (In Persian with English abstract)

Bagheri, A., M. H. Rashed Mohassel, P. Rezvani Moghadam and M. Nasiri Mahalati. 2010. Evaluation of spatial distribution and weed dynamics in a wheat field. Iran J. Field Crops Res. 8(4): 646-657. (In Persian with English abstract)

Blackshaw, R. E. 2005. Nitrogen Fertilizer, manure, and compost effects on weed growth and competition with spring wheat. Agron. J. 97(6): 1612-1621.

Brim-DeForest, W. B., K. Al-Khatib and A. J. Fischer. 2017. Predicting yield losses in rice mixed-weed species infestations in California. Weed Sci. 65(1): 61-72.

Cierjacks, A., M. Pommeranz, K. Schulz and J. Almeida-Cortez. 2016. Is crop yield related to weed species diversity and biomass in coconut and banana fields of northeastern Brazil? Agric. Ecosyst. Environ. 220:175-183.

Erman, M., I. Tepe, B. Bukun, R. Yergin and M. Taskesen. 2008. Critical period of weed control in winter lentil under non-irrigated conditions in Turkey. Afr. J. Agric. Res. 3(8): 523-530.

Esfandiari H and S. H. Hashemi Jozi. 2002. Effect of plant density and herbicide application on weed control in bean. $7^{\text {th }}$ Iranian Congress of Agricultural Sciences and Plant Breeding, 5-7 Sep. 2002, Seed and Plant Improvement Institute. Karaj. (In Persian with English abstract).

Fahad, S., S. Hussain, S. Saud, S. Hassan, H. Muhammad, D. Shan, C. Chen, C. Wu, D. Xiong and S. Khan. 2014. Consequences of narrow crop row spacing and delayed Echinochloa colona and Trianthema portulacastrum emergence for weed growth and crop yield loss in maize. Weed Res. 54(5): 475-483.

Gerhards, R., D. Dicke and H. Oebel. 2005. Testing and analysing decision rules for site-specific weed control in malt barley (Hordeum vulgare L.) using a geographic information system. J. Plant Dis. Protec. 112(5): 447-456.

Heisel, T., A. K. Ersbøll and C. Andreasen. 1999. Weed mapping with Co-Kriging using soil properties. Precision Agric. 1(1): 39-52.

Koller, M. and W. T. Lanini. 2005. Site-specific herbicide applications based on weed maps provide effective control. California Agric. 59(3): 182-187.

Lehnhoff, E. A., Z. J. Miller, M. J. Brelsford, S. White and B. D. Maxwell. 2013. Relative canopy height influences wild oat (Avena fatua) seed viability, dormancy, and germination. Weed Sci 61(4): 564-569.

Liebman, M. and E. Dyck. 1993. Crop rotation and intercropping strategies for weed management. Ecol. Appl. 3(1): $92-122$.

Liu ,Y., J. Lv, B. Zhang and J. Bi. 2013. Spatial multi-scale variability of soil nutrients in relation to 


$$
\text { " ارزيابى اثر ير اكنش مكانى علفهاى هرز.... نخين زر گريان و همكاران، }
$$

environmental factors in a typical agricultural region. Eastern China. Sci. Total Environ. 450:108-119.

Makarian H and R. Hosseini 2010. Spatial distribution of weeds and its effect on wheat (Triticum aestivum L.) biomass. J.Crop Prod. 3 (4): 31-47. (In Persian with English abstract).

Makarian, H. and a. Rohani. 2014. Determination of weed spatial distribution based on damage threshold in two winter wheat (Triticum aestivum L.) fields in Shahrood region. J. Plant Prod. Res. 21(3): 51-73. (In Persian with English abstract)

Milberg, P. and E. Hallgren. 2004. Yield loss due to weeds in cereals and its large-scale variability in Sweden. Field Crop Res. 86(2): 199-209.

Mohammadi, J. 1999. Study of the spatial variability of soil salinity in Ramhormoz area (Khuzestan) using geostatistical theory Il. Cokriging. J. Water Soil Sci. 3(1): 1-8. (In Persian with English abstract)

Myers, M. W., W. S. Curran ,M. J. Vangessel, B. A. Majek, B. A. Scott, D. A. Mortensen, D. D. Calvin, H. D. Karsten and G. W. Roth. 2005. The effect of weed density and application timing on weed control and corn grain yield. Weed Technol. 19(1): 102-107.

Rajcan, I., K. J. Chandler and C. J. Swanton. 2004. Red-far-red ratio of reflected light: a hypothesis of why early-season weed control is important in corn. Weed Sci. 52(5): 774-778.

Sarker, A. and W. Erskine. 2006. Recent progress in the ancient lentil. J. Agric. Sci. 144(1): 19-29.

Saxena M., K. Subramanyam and D. Yadav. 1976. Chemical and mechanical control of weeds in gram (Cicer arietinum L.). Pantnagar J. Res. 1: 112-116.

Schroeder, J., S. H. Thomas and L. W. Murray. 2005. Impacts of crop pests on weeds and weed-crop interactions. Weed Sci. 53(6): 918-922.

Seyed Jalali, S. A. and M. Shorafa. 2016. Application of Kriging and Cokriging in predicting wheat yield using principle component analysis. Sci J. Manage. Sys. 9(2): 213-224.

Siah Marguee , A., M. H. Rashed Mohassel, M. Nasiri Mahallati, M. Banayan Awal and H. Mashhadi. 2006. Evaluation of spatial variation of weeds and their response to imposed managements in a sugar beet field in Mashhad. J. Water. Soil. Sci.. 10(3): 361-374. (In Persian with English abstract)

Song, J. S., J. W. Kim, J. H. Im, K. J. Lee, B. W. Lee and D. S. Kim. 2017. The effects of single and multiple weed interference on soybean yield in the far-eastern region of Russia. Weed Sci. 65(3): 371-380.

Thorp, K. R. and L. F. Tian. 2004. A Review on remote sensing of weeds in agriculture. Precision Agric. 5(5): 477-508.

Walter, A. M., S. Christensen and S. E. Simmelsgaard. 2002. Spatial correlation between weed species densities and soil properties. Weed Res. 42(1): 26-38.

Yenish J. P., J. Brand, M. Pala and A. Haddad. 2009. Weed Management In Lentil. In: Erskine, W., Muehlbauer, F., Sarker, A., Sharma, B. (Eds.), The Lentil: Botany, Production and Uses. MPG Books Group, Wallingford, UK. 
"نشريه علوم زراعى ايران"، جلد بيست و دوم، شماره r، تابستان \$ج9|

\title{
Evaluation of the effect of spatial distribution of weeds on seed yield of lentil (Lens culinaris L.) in rainfed conditions
}

\author{
Zargarian, N. ${ }^{1}$, A. R. Bagheri ${ }^{2}$, I. Nosrati ${ }^{3}$ and F. Mondani ${ }^{4}$
}

\begin{abstract}
Zargarian, N., A. R. Bagheri, I. Nosrati and F. Mondani. 2020. Evaluation of the effect of spatial distribution of weeds on seed yield of lentil (Lens culinaris L.) in rainfed conditions. Iranian Journal of Crop Sciences. 22(2): 140-151. (In Persian).

Weeds are one of the most important factors in reducing yield in legumes crops. Therefore, awareness of the interaction between weeds and crops as well as identification of their spatial variation pattern in the field is important. To investigate the the effect of weeds on seed yield of lentil, and also to study the spatial distribution pattern of weeds under rainfed conditions, a field experiment was conducted in research field of agricultural and natural resources campus, Razi University, Kermanshah, Iran, in 2016. Systematic samplings and measuremnts weeds characteristics (density, canopy percentage, height and dry weight) and lentil (canopy percentage and seed yield) were carried out in two stages; pre-flowering and physiological maturity of lentil. The relationships between weeds and lentil were studied using regression and maps of weeds and lentil traits using Kriging interpolation method. The results showed that by increasing the density and canopy percentage of weeds from 0 to 10 (plants. $\mathrm{m}^{-2}$ or percentage), the seed yield of lentil decreased by 6.2 and $6.7 \mathrm{~g} . \mathrm{m}^{-2}$, respectively. Furthermore, increasing weeds dry matter from 0 to 10 g.m ${ }^{-2}$ led to a decrease in lentil seed yield by 2.4 g.m $\mathrm{m}^{-2}$. The spatial distribution maps also clearly showed the spatial variations of seed yield under the influence of weeds. In conclusion, the results of this study showed that spatial maps of weeds and lentil traits distributionas well as conventional statistical methods are complementary and accurate method for better understanding of the relationships between them.
\end{abstract}

Key words: Competition of weeds, Geostatistics, Legumes, Lentil and Yield loss.

\footnotetext{
Received: October, 2019 Accepted: December, 2019

1. MSc Student, Razi University, Kermanshah, Iran

2. Assistant Prof., Razi University, Kermanshah, Iran (Corresponding author) (Email: a.bagheri@ razi.ac.ir)

3. Assistant Prof., Razi University, Kermanshah, Iran

4. Assistant Prof., Razi University, Kermanshah, Iran
} 